\title{
Recurrent Takotsubo Cardiomyopathy
}

\author{
Tekrarlayan Takotsubo Kardiyomiyopati
}

\author{
Erkan Yıldırım, Emrah Ipek, Emrah Ermiş, Selami Demirelli \\ Erzurum Bölge Training and Research Hospital, Clinic of Cardiology, Erzurum, Turkey
}

\begin{abstract}
Stress-induced cardiomyopathy or takotsubo syndrome is a transient cardiac dysfunction which is precipitated by intense emotional or physical stress. It mimics acute coronary syndrome clinically (chest pain and dyspnea) and has specific echocardiographic findings in the absence of significant coronary stenosis. The underlying pathophysiologic mechanism is mostly due to stress-induced catecholamine release. This syndrome is more commonly seen in females especially in the postmenopausal period. The prognosis of stress-induced cardiomyopathy is usually favorable with a prevalence of in-hospital mortality of less than $2 \%$. Reports of a single episode of stress-induced cardiomyopathy are common in the literature, but recurrence of stressinduced cardiomyopathy is rare. Herein, we present an uncommon case of recurrent stress-induced cardiomyopathy in order to provide an explanation of the pathophysiology of this unique syndrome.
\end{abstract}

Keywords: Acute coronary syndrome, takotsubo, recurrent
Öz

Strese bağlı kardiyomiyopati yoğun duygusal ya da fiziksel stres tarafından tetiklenen geçici kardiyak disfonksiyon sendromudur. Belirgin koroner arter hastalığı yokluğunda, spesifik ekokardiyografik bulgular ve klinik prezentasyon (göğüs ağrısı ve dispne) akut koroner sendromu taklit edebilir. Patofizyoloji sıklıkla stresin tetiklediği katekolamin salınımı ile ilişkilidir. Sendrom, çoğunlukla postmenopozal yaş grubu kadınlarda sıktır. \%2'den daha az hastane içi mortalite ile prognozu iyidir. Tek epizodlu strese bağlı kardiyomiyopati literatürde yaygındır fakat tekrarlayan epizodlu olgular nadirdir. Bu sendromun doğasının daha iyi anlaşılması için bu olguyu sunduk.

Anahtar Sözcükler: Akut koroner sendrom, takotsubo, tekrarlayan

\section{Introduction}

Stress-induced cardiomyopathy (SIC) is a non-ischemic cardiomyopathy with reversible left ventricular (LV) dysfunction which is mostly seen in post menopausal women. It is also known as takotsubo cardiomyopathy, broken heart syndrome and transient LV apical ballooning syndrome. An apparent relationship of emotional and physical stress, and adverse cardiac events, such as myocardial infarction (MI), with death has been reported $(1,2)$. Recurrence of this disease is rarely observed. Until now, in large series, the rate of recurrence has been reported to be $2.7 \%$ (3).

\section{Case}

A 56-year-old female patient with a history of hypertension and hyperlipidemia was admitted to our emergency clinic with the complaint of chest pain just after she heard about her mother's death. Initial physical examination was normal. Electrocardiography (ECG) revealed negative $T$ waves in precordial $V 1$ to V6 leads (Figure 1). The troponin I level was $2.39 \mu \mathrm{g} / \mathrm{L}$ (normal reference value is $<0.1 \mu \mathrm{g} / \mathrm{L}$ ). In transthorasic echocardiography, the ejection fraction was 30\% and LV apical and mid segments were akinetic with basal segment hyperkinesia. Coronary angiography was normal with an impaired ventriculography which showed akinetic apical and mid, and hyperkinetic basal segments (Figure $2 \mathrm{a}, 2 \mathrm{~b})$. A therapy with aspirin $100 \mathrm{mg}$ po qd, perindopril $5 \mathrm{mg}$ po qd, metoprolol $50 \mathrm{mg}$ po qd with a twice daily subcutaneous injection of 0.6 cc enoxoparine was started. She was hemodynamically stable during follow-up. After four days, she was discharged on aspirin $100 \mathrm{mg}$ po qd, perindopril $5 \mathrm{mg}$ po qd, metoprolol $50 \mathrm{mg}$ po qd. On the second week, during transthorasic echocardiography, we detected normal LV systolic functions. Her ECG and troponin level were also found to be normal.
Address for Correspondence/Yazışma Adresi: Erkan Yıldırım Erzurum Bölge Training and Research Hospital, Clinic of Cardiology, Erzurum, Turkey E-mail: drerkan23@yahoo.com

Received/Geliş Tarihi: 24 January 2016 Accepted/Kabul Tarihi: 05 March 2016
The Medical Bulletin of Haseki Training and Research Hospital, published by Galenos Publishing.

Haseki Tıp Bülteni, Galenos Yayınevi tarafından basılmıştır. 
Eight weeks after discharge, she was admitted to our emergency clinic with similar complaints which started again just after she heard about the loss of her sister. We have detected similar ECG findings with negative precordial T waves (Figure 1b). The troponin I was 1.28 $\mu \mathrm{g} / \mathrm{L}$. The second coronary angiogram was normal with similar previous ventriculographic and echocardiographic findings. After stabilization, she was discharged on the same therapy. In the echocardiography after four weeks, the LV functions were found to be normal.

\section{Discussion}

SIC has been classified as a cardiomyopathy since 2006 by American Heart Society (4). According to the case reports and reviews in the literature, the incidence of SIC is between $1.5 \%$ and $2.2 \%$ in patients with suspected acute anterior MI $(3,5)$.

$\mathrm{SIC}$ is more commonly detected in postmenopausal females compared to males (6). Although the underlying pathophysiologic mechanism is unclear, sudden cathecholamine discharge plays some important role in this syndrome. In some animal studies, cathecholamine discharge was shown to be able to lead myocardial injury $(7,8)$.

Emotional and physical traumas are the main causes of this disease. Emotional stress, such as death or sickness of the loved one, arguments, armed robbery and financial loss, and physical stress, such as vigorous exercise, swimming, alcohol deprivation, cocaine abuse and non cardiac surgery can trigger this syndrome $(7,8)$. In our patient, the death of her mother and sister possibly had triggered the event.

SIC can mimic ACS clinically. The most common symptom is chest pain. As a result of decreased stroke volume, hypotension and dyspnea can be observed. Syncope and cardiac arrest can be rarely seen. The clinical presentation of the patients can be variable in a spectrum from mild to severe. $20 \%$ of patients need inotropic support or intraaortic balloon pump. The hemodynamic parameters of our patient were normal in both hospitalizations. In most of the patients, precordial ST segment elevation or typical diffuse T wave negativity

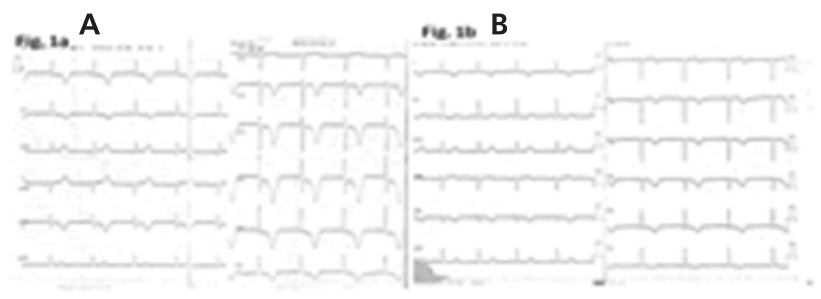

Figure 1A, B. Electrocardiography sinus rhythm with negative precordial T waves is common (6). The ECG changes are generally related to mild troponin elevation (6). The mild troponin elevation and diffuse T wave negativity in our patient was consistent with the previous data. LV apical and mid segment akinesia and basal segment hyperkinesia are generally observed during echocardiography. The exact cause of apical and mid segment involvement of LV is still unknown. However, it is speculated that apical segment is more prone to symphathetic stimulation or has an increased density of cathecholamine sensitive receptors $(9,10)$. Coronary angiography is the gold standard for diagnosis and is not correlated well with ECG and echocardiographic findings (6). Since the presentation mimics ACS, the initial therapy should be similar to the ACS treatment. After diagnosis, ACE inhibitor and beta blocker therapy should be started because of LV dysfunction. Thrombocyte aggregation is assumed to be increased in these patients; as a result, antithrombotics should be added to the therapy (6). In about $20 \%$ of patients, the most common complication is heart failure more likely affecting the right ventricular myocardium. In these cases, diuretics and vasodilators can be effective therapeutic options. Cardiogenic shock with LV failure can be seen and balloon counter pulsation is usually needed. In order to prevent thromboembolism, anticoagulation may be an option in patients with unresolved hypokinesis. The short-and long-term prognosis is favorable. Additionally, the long-term survival does not differ from that in the general age-matched individuals (6). In-hospital mortality rate varies from $0 \%$ to $8 \%$. From the point of view of associated mortality, the outcome is slightly worse than in the normal population, however, it is better than in patients with Ml. Recurrence of this syndrome is uncommon. In the largest series with 88 patients so far the recurrence rate has been reported to be $2.7 \%$ (3). We

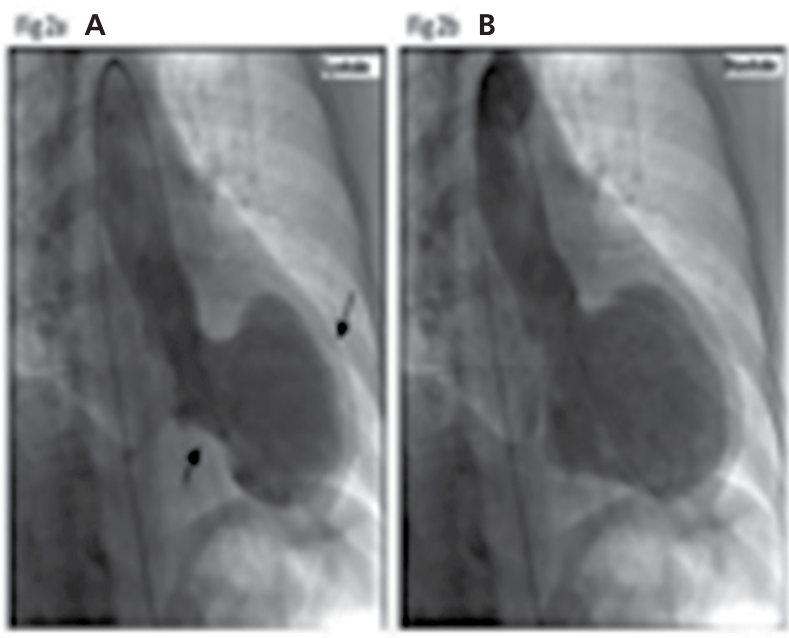

Figure 2A, B. Ventriculography with left ventricular systolic (2a) diastolic (2b) images showing akinesia *in apical and mid, and hyperkinesia* in basal segments ( ${ }^{*}$ shown with arrow) 
have presented this SIC case since it is uncommon, caused by emotional stress and was recurrent.

\section{Ethics}

Informed Consent: Informed consent was obtained from all patients.

Peer-review: Externally peer-reviewed.

\section{Authorship Contributions}

Surgical and Medical Practices: Erkan Yıldırım, Emrah İpek. Concept: Erkan Yıldırım, Emrah Ermiş. Design: Erkan Yıldırım, Emrah Ipek. Data Collection or Processing: Erkan Yıldırım, Selami Demirelli. Analysis or Interpretation: Erkan Yıldırım, Selami Demirelli. Literature Search: Emrah Ermiş, Emrah Ipek. Writing: Erkan Yıldırım, Emrah Ipek.

Conflict of Interest: No conflict of interest was declared by the authors.

Financial Disclosure: The authors declared that this study has received no financial support.

\section{References}

1. Willich $S N$, Maclure $M$, Mittleman $M$, et al. Sudden cardiac death. Support for a role of triggering in causation. Circulation 1993;87:1442-50.

2. Muller JE, Abela GS, Nesto RW, et al. Triggers, acute risk factors and vulnerable plaques: the lexicon of a new frontier. J Am Coll Cardiol 1994;23:809-13.

3. Elian D, Osherov A, Matetzky S, et al. Left ventricular apical ballooning: not an uncommon variant of acute myocardial infarction in women. Clin Cardiol 2006;29:9-12.
4. Maron BJ, Towbin JA, Thiene G, et al. Contemporary definitions and classification of the cardiomyopathies: an American Heart Association Scientific Statement from the Council on Clinical Cardiology, Heart Failure and Transplantation Committee; Quality of Care and Outcomes Research and Functional Genomics and Translational Biology Interdisciplinary Working Groups; and Council on Epidemiology and Prevention. Circulation 2006;113:1807-16.

5. Parodi G, Del Pace S, Carrabba N, et al. Incidence, clinical findings, and outcome of women with left ventricular apical ballooning syndrome. Am J Cardiol 2007;99:182-5.

6. Kotla SK, Nathaniel C. Recurrent stress-induced cardiomyopathy: a case report and review article. Case Rep Med 2011;2011:160802.

7. Ueyama T, Kasamatsu K, Hano T, et al. Emotional stress induces transient left ventricular hypocontraction in the rat via activation of cardiac adrenoceptors: a possible animal model of 'tako-tsubo' cardiomyopathy. Circ J 2002;66:712-3.

8. Ueyama T, Senba E, Kasamatsu K, et al. Molecular mechanism of emotional stress-induced and catecholamine-induced heart attack. J Cardiovasc Pharmacol 2003;41 Suppl 1:115-8.

9. Lyon AR, Rees PS, Prasad S, et al. Stress (Takotsubo) cardiomyopathy-a novel pathophysiological hypothesis to explain catecholamine-induced acute myocardial stunning. Nat Clin Pract Cardiovasc Med 2008;5:22-9.

10. Mori H, Ishikawa S, Kojima S, et al. Increased responsiveness of left ventricular apical myocardium to adrenergic stimuli. Cardiovasc Res 1993;27:192-8. 